\title{
THE EFFECTS OF THYROXINE HORMONE ON GONADAL MATURATION AND GROWTH OF MALE SPINY LOBSTER (PANULIRUS HOMARUS)
}

\author{
Yudha Trinoegraha Adiputra ${ }^{1 a}$, Muhammad Zairin $\mathbf{J r}^{2 b^{*}}$, Muhammad Agus \\ Suprayudi $^{3 \mathrm{c}}$, Wasmen Manalu ${ }^{4 \mathrm{c}}$, Widanarni ${ }^{5 \mathrm{~b}}$ and Margie Brite ${ }^{6 \mathrm{~d}}$ \\ ${ }^{a}$ Department of Fisheries and Marine Science, Faculty of Agriculture, University of Lampung, INDONESIA. \\ Email:yudha_adiputra@yahoo.com ${ }^{1}$ \\ ${ }^{b}$ Department of Aquaculture, Faculty of Fisheries and Marine Science, IPB University, INDONESIA. Email: \\ zairinmz@live.com ${ }^{2}$; widanarni@apps.ipb.ac.id ${ }^{5}$ \\ 'Department of Anatomy, Physiology, and Pharmacology, Faculty of Veterinary Medicine, IPB University, \\ INDONESIA. Email: agus.suprayudi1965@gmail.com ${ }^{3}$; wasmenmanalu@ymail.com ${ }^{4}$ \\ ${ }^{\mathrm{d}}$ Lampung Main Center for Marine Aquaculture, INDONESIA. Email : britemargie@ gmail.com ${ }^{6 \mathrm{~d}}$ \\ Corresponding author: zairinmz@live.com \\ Received: $2^{\text {nd }}$ Aug $2018 \quad$ Accepted: $19^{\text {th }}$ Aug 2019 \\ Published: $29^{\text {th }}$ Feb 2020
}

DOI: https://doi.org/10.22452/mjs.vol39no1.3

\begin{abstract}
The present experiments were designed to find the optimum dose of thyroxine hormone to enhance the gonadal maturation and growth of male spiny lobsters (Panulirus homarus). The maturation study used 30 male spiny lobsters divided into two treatments of weekly thyroxine hormone injections of 0 and $0.1 \mu \mathrm{g} / \mathrm{g}$, respectively. Samples were taken to determine the following parameters: the gonadosomatic index (GSI), the anatomy, and the histology of the gonads. The growth study used 44 male spiny lobsters divided into four treatments of weekly thyroxine injections of $0,0.1,0.2$, and $0.5 \mu \mathrm{g} / \mathrm{g}$, respectively, over 70 days of culture. The following growth parameters were observed: the specific growth rate (SGR), the growth of carapace length (GCL), the number of molted male spiny lobsters, the feed conversion ratio (FCR), and the survival rate (SR). The results showed that injection of thyroxine hormone at a dose of $0.1 \mu \mathrm{g} / \mathrm{g}$ supported optimum SGR, GCL, FCR, molting, and SR. Moreover, male spiny lobsters injected with thyroxine at a dose of $0.1 \mu \mathrm{g} / \mathrm{g}$ experienced increased GSI $(P<0.05)$, showing better gonad development and a higher number of spermatogonia.
\end{abstract}

Keywords: growth, male gonad anatomy, Panulirus, spermatogonia, thyroid

\section{INTRODUCTION}

The aquaculture of spiny lobster, Panulirus homarus (Linnaeus, 1758), in Indonesia has been limited to the culture and rearing of naturally captured grower puerulus (Priyambodo et al., 2017). Jones (2010) declared that the culture and rearing of grower puerulus both depend on natural capture due to poorly established hatchery technology. The success of spiny-lobster hatcheries in is related to the use of selected egg-berried brood stock or immature brood stock with strict health and fitness requirements obtained from fishermen or live seafood markets (Jones, 2009; Hall et al., 2013). In these situations, the brood stocks need to be kept in a culture prior to more mature stages and body weight for reproduction purposes (Phillips \& Matsuda, 2011). Hormonal manipulation may enhance the maturity and growth of male spiny lobsters; however, research of its use in spiny-lobster aquacultures is scarce. 
Thyroxine hormone plays critical roles in the organogenesis, growth, and metabolism regulation of both fish and mammals (Nelson \& Habibi, 2009). Recently, thyroxine has received attention for applications in both fish and crustaceans, being shown to enhance the reproduction process and growth of rainbow trout (Salmo gairdneri) (Sullivan et al., 1989), rabbit fish (Siganus guttatus) (Ayson \& Lam, 1993), Coho salmon (Oncorhynchus kisutch) (Ebberson et al., 2000), Atlantic halibut (Hippoglossus hippoglosus) (Einarsdóttir et al., 2006), and Persian sturgeon (Acipenser persicus) (Kamangar et al., 2007). The use of thyroxine in crustaceans, however, has not grown rapidly, even though its administration in low doses has been found to enhance the maturation of the reproduction organs and growth of black tiger shrimp (Penaeus monodon) (Pillai et al., 1987), giant freshwater shrimp (Macrobrachium rosenbergii) (Roustaian \& Gaik, 2006), and mud crab (Scylla serrata) (Iromo et al., 2014a, 2014b, 2015).

Information is limited, however, about thyroxine applications to enhance the gonadal maturation and growth of male spiny lobsters, which are needed as a practical method to develop spiny-lobster hatchery systems. This experiment was designed to study the optimal dose of thyroxine to support the gonadal maturation and growth of male spiny lobsters.

\section{MATERIALS AND METHODS}

\subsection{Origin and Captivity of Spiny Lobsters and Thyroxine Hormone Injection}

Live, male spiny lobsters were bought from local lobster dealers in Krui, West Coast Residence, Lampung Province, Indonesia. Lobster dealers obtained the spiny lobsters from local fishermen, who caught them from surrounding West Coast water. The lobsters were handled with sea sand and ice before being packed into paper boxes. The transportation of the caught spiny lobsters took six hours by car to the Main Center for Marine Aquaculture (MCMA) in Pesawaran Residence, Lampung Province. The permit clearance to use the spiny lobsters for research purposes was obtained from the Fish Quarantine and Fisheries Quality Inspection Office, Lampung Province.

The male spiny lobsters were fed and kept for a seven-day adaptation period in a culture environment. Six fiberilluminated plastic tanks with the dimensions $250 \mathrm{~cm} \times 100 \mathrm{~cm} \times 50 \mathrm{~cm}$ were filled with sea water to $40 \mathrm{~cm}$. Continuous water change and aeration were used during the rearing of the experimental spiny lobsters. Fresh squid and fish meat were used as feeds during the experiment. The experimental spiny lobsters were fed twice a day at 07 am and $04 \mathrm{pm}$ with food weighing from 3-5\% of their body weights. The experimental tanks were siphoned and cleaned twice daily at 08 am and $05 \mathrm{pm}$. For a shelter to protect the experimental lobsters in captivity during the experiment, each experimental tank had a polyvinyl chloride (PVC) pipe with a 6-inch diameter and a length of $30 \mathrm{~cm}$. During the adaptation period prior to the experiment, the experimental male spiny lobsters were selected. Lobsters that showed weak performances, unhealthy conditions, and incomplete organs by autotomy were not used in the experiment. Similar methods were used to maintain the experimental lobsters in an adaptation period during gonadal maturation and growth.

Levothyroxine sodium (Thyrax N.V., Organon, Oss, Netherlands) with a thyroxine concentration of $100 \mu \mathrm{g}$ in $1 \mathrm{~g}$ tablets was used as the source of thyroxine hormone in this study. The stock solution for thyroxine injection was made by crushing 1 tablet to powder and dissolving it in $100 \mu \mathrm{L}$ of physiological $\mathrm{NaCl}(0.9 \mathrm{~g}$ of 
$\mathrm{NaCl}$ and $100 \mu \mathrm{L}$ of sterile $\mathrm{ddH}_{2} \mathrm{O}$ ). A serial dilution was also made to obtain the required concentrations. The injection of the thyroxin in doses of $0 \mu \mathrm{g} / \mathrm{g}$ was made with $1 \mathrm{~mL}$ of physiological $\mathrm{NaCl}$ without any thyroxine.

\subsection{Gonadal maturation study}

The gonadal maturation study used 30 male spiny lobsters with body weights from

121-178 g. The doses of the thyroxine injections were 0 and $0.1 \mu \mathrm{g} / \mathrm{g}$ for the control and treatment groups, respectively, 15 males receiving each dose. The thyroxine injections were conducted once a week. Samples of male spiny lobsters were taken on days $3,7,10,14$, and 21 after the weekly thyroxine injection. The gonadosomatic indices (GSI) of the lobsters (the percentage of gonad weight divided by body weight), as well as their gonad anatomy and histology, were measured and compared between treatments. Clove oil at a concentration of $10 \mathrm{~mL} / \mathrm{L}$ in sea water was used as an anesthetic agent before body sectioning. The body weights of the lobsters were measured with a digital balance accurate within $0.01 \mathrm{~g}$.

Bhujel (2008) was used to calculate Student's $t$-test from two GSI means of all samples and days at a 95\% significance. The gonad anatomy of all the experimental lobsters was determined by digital camera photos reconstructed in Adobe Photoshop CS. Gonad histology preparation and analysis were conducted following the protocols of Bell and Lightner (1988) and Shields and Boyd (2014). One gonad chosen by random sampling was taken for each day of treatment for histology observation.

\section{$2.3 \quad$ Growth study}

The growth study used 44 male spiny lobsters with initial body weights from 92-140 g. Four weekly thyroxine injections of doses $0,0.1,0.2$, and $0.5 \mu \mathrm{g} / \mathrm{g}$ were administered to 11 lobsters each, which were subsequently cultured for 70 days. The following growth parameters were measured: initial and final body weights to obtain the SGR, initial and final carapace lengths to obtain the GCL, the number of molted male spiny lobsters, the FCR, and the SR of the experimental male spiny lobsters. The SGR was the percentage of daily weight gain calculated from the natural $\log$ function of final body weight minus the natural log function of initial weight divided by 70 days. Carapace lengths were measured from the rostrum to the final part of the cephalothorax using a digital caliper accurate within $0.1 \mathrm{~mm}$. The GCL was the daily percentage of carapace gain calculated by subtracting the final carapace length from the initial carapace length divided by the initial carapace length.

The number of molted male spiny lobsters was the number of male spiny lobster that reached their molting phase within the 70 days of culture. The FCR was calculated by dividing the total given feed during the culture divided by the weight gain during the culture period. The SR was the percentage of live spiny lobsters after 70 days of culture divided by the initial number of live spiny lobsters. An individual replication from each dose was used to calculated both the SGR and CLG and was then analyzed using one-way ANOVA with SPSS version 24 at a $95 \%$ significance. The other growth parameters were analyzed descriptively between treatments. 


\section{RESULTS}

The gonadal maturity study showed that the injection of male spiny lobsters with thyroxine at a dose of $0.1 \mu \mathrm{g} / \mathrm{g}$ had a positive effect on the GSI. The daily gonad growth during sample measurements amply demonstrated this effect, as the gonads of lobsters receiving the injection of thyroxine at a dose of $0.1 \mu \mathrm{g} / \mathrm{g}$ grew significantly more than those of the control group without the injection $(P<0.05)$ (Figure 1$)$. In addition, the gonadal maturity in the male spiny lobsters injected with thyroxine at a dose of $0.1 \mu \mathrm{g} / \mathrm{g}$ was clearly more advanced than both the immature and mature gonads found in male spiny lobsters without the injection. Natural anatomical changes (after body sectioning) were observed with rounded, bigger vas deferens and longer testes (Figure 2). Moreover, the histological analyses of the gonads also clearly showed that the injection of thyroxine at a dose of $0.1 \mu \mathrm{g} / \mathrm{g}$ sped up gonad maturation, as was indicated by the more abundant spermatogonia. In contrast, in male spiny lobsters injected with thyroxine at a dose of $0 \mu \mathrm{g} / \mathrm{g}$, no spermatogonia was found in the gonads (Figure 3).

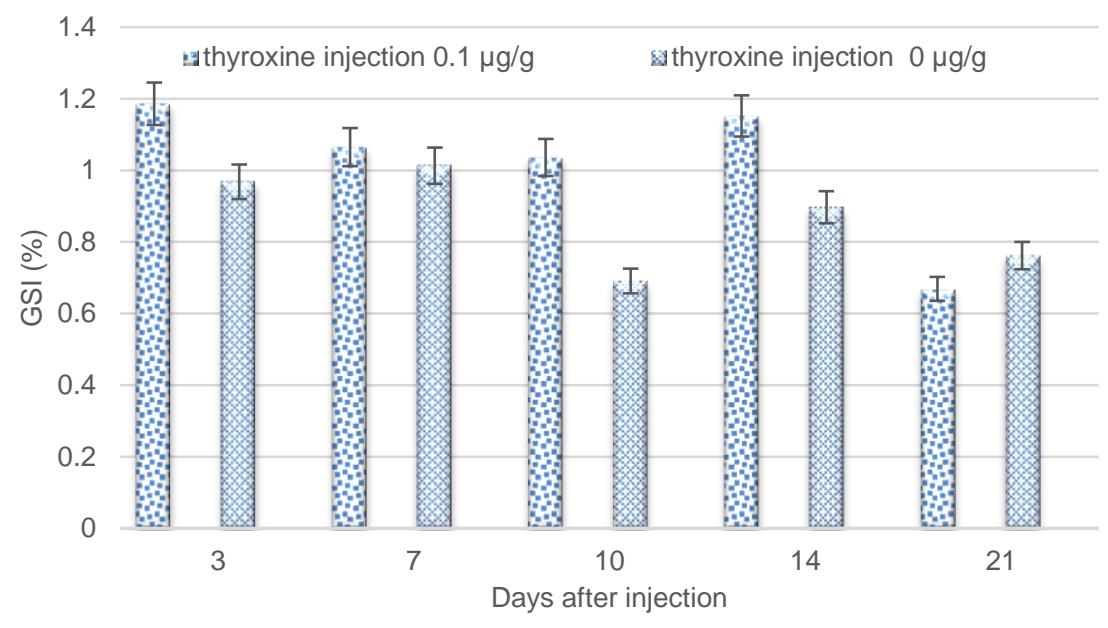

Figure 1. GSI (\%) of male spiny lobsters (Panulirus homarus) injected with thyroxine hormone at doses of 0.1 and $0 \mu \mathrm{g} / \mathrm{g}(P<0.05)$.

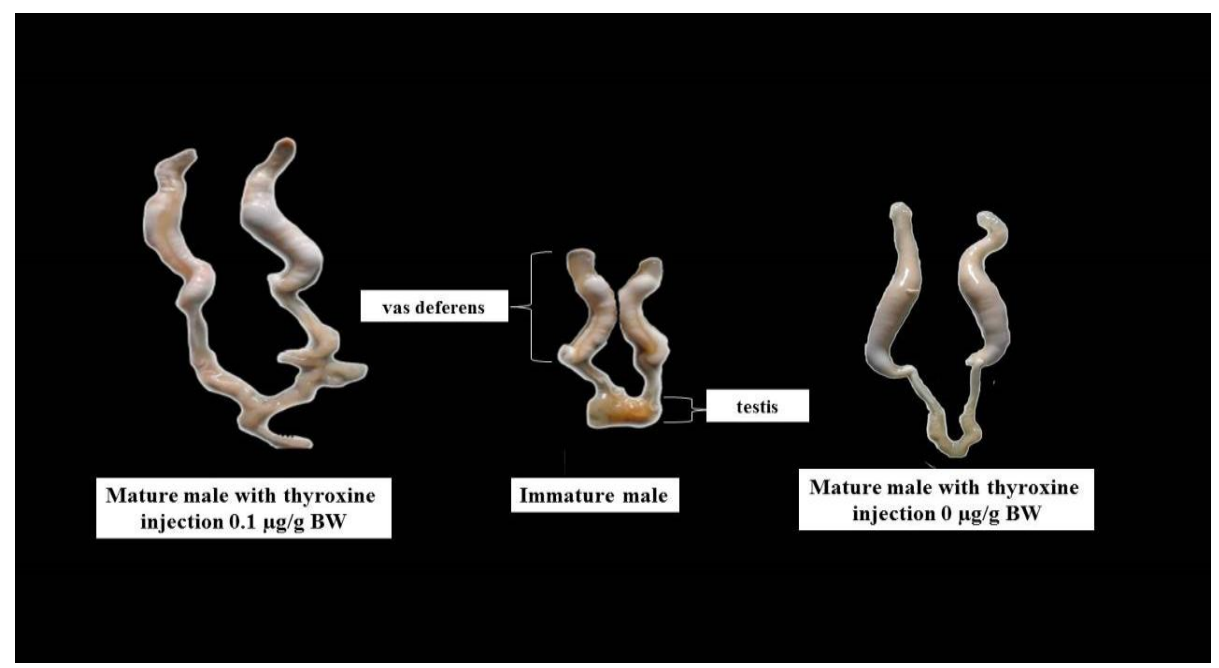

Figure 2. Mature and immature gonad anatomy of male spiny lobsters (Panulirus homarus) injected with thyroxine doses of 0 and $0.1 \mu \mathrm{g} / \mathrm{g}$. Bigger, rounded vas deferens and longer testes indicated mature gonads due to injection of thyroxine at a dose of $0.1 \mu \mathrm{g} / \mathrm{g}$ (figure not to scale). 


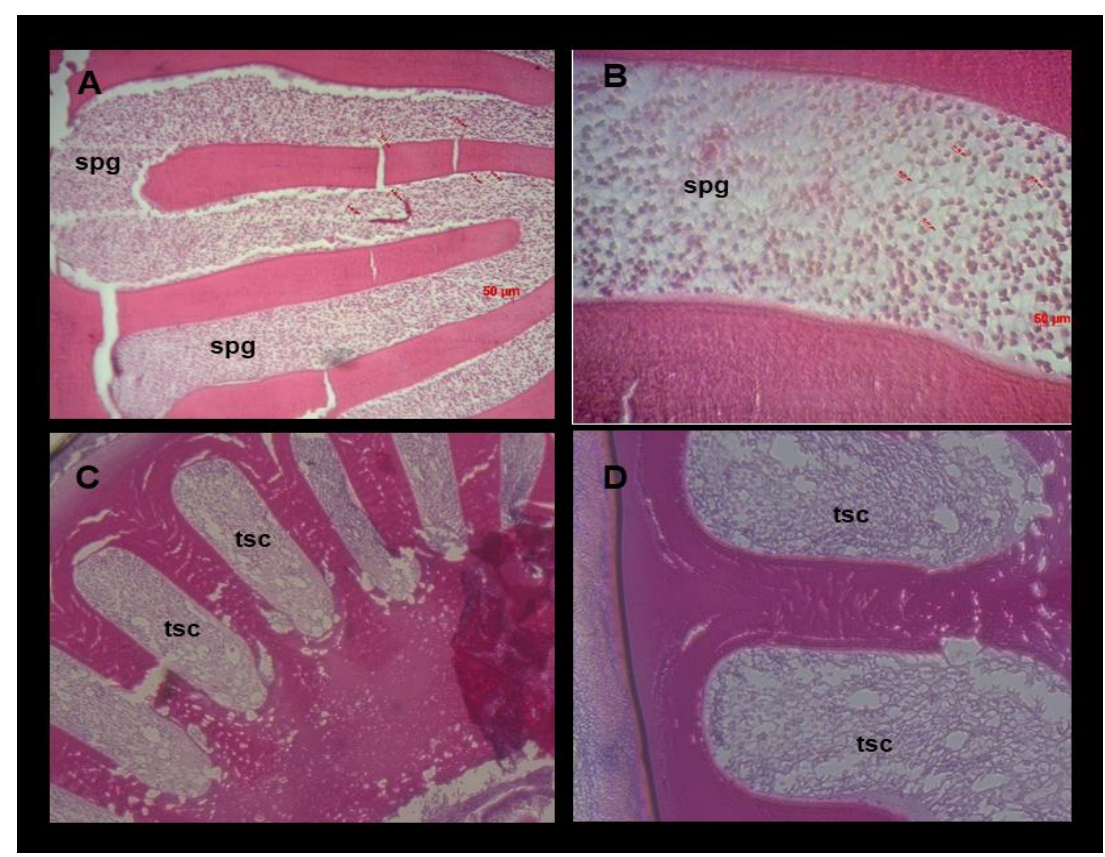

Figure 3. Mature gonad of a male spiny lobster (Panulirus homarus) injected with a thyroxine dose of $0.1 \mu \mathrm{g} / \mathrm{g}$ (body weight $135 \mathrm{~g}$; H\&E staining; 100\&400x). Spermatogonia (spg) appeared in testis canals in a variety of sizes. (A, B) Mature gonad without thyroxine injection, $0 \mu \mathrm{g} / \mathrm{g}$ (body weight $139 \mathrm{~g}$; H\&E staining; 100\&400x). (C, D) Undeveloped testis canal (tsc) with no visible spermatogonia.

The growth of male spiny lobsters injected with thyroxine at a dose of $0.1 \mu \mathrm{g} / \mathrm{g}$ showed better culture performances than male spiny lobsters injected with thyroxine hormone at doses of $0,0.2$, and $0.5 \mu \mathrm{g} / \mathrm{g}$ (Table 1). The SGR and GCL in male spiny lobsters injected with thyroxine at a dose of $0.1 \mu \mathrm{g} / \mathrm{g} \quad$ were the highest at 0.09 and $2.80 \%$ per day, respectively, and significantly different $(P<0.05)$ than those injected with thyroxine at doses of $0,0.2$, and $0.5 \mu \mathrm{g} / \mathrm{g}$. These results indicate that final body weight and carapace length for lobsters injected with $0.1 \mu \mathrm{g} / \mathrm{g}$ of thyroxine were higher than those injected with thyroxine at doses of $0,0.2$, and $0.5 \mu \mathrm{g} / \mathrm{g}$ (Table 1).

Table 1. Growth parameters of male spiny lobsters (Panulirus homarus) injected with various doses of thyroxine hormone.

\begin{tabular}{|c|c|c|c|c|c|}
\hline \multirow[t]{2}{*}{ No. } & \multirow[t]{2}{*}{ Parameters } & \multicolumn{4}{|c|}{ Doses of thyroxine injection $(\mu \mathrm{g} / \mathrm{g})$} \\
\hline & & 0 & 0.1 & 0.2 & 0.5 \\
\hline 1 & Initial weight $(\mathrm{g})$ & $113.72 \pm 1.41$ & $111.27 \pm 1.83$ & $108.00 \pm 1.82$ & $117.27 \pm 1.34$ \\
\hline 2 & Final weight $(\mathrm{g})$ & $119.10 \pm 3.53$ & $118.63 \pm 1.83$ & $112.00 \pm 1.41$ & $121.80 \pm 1.83$ \\
\hline 3 & Specific growth rate (\%/day) ${ }^{*}$ & $0.06^{\mathrm{a}}$ & $0.09^{\mathrm{b}}$ & $0.05^{\mathrm{a}}$ & $0.05^{\mathrm{a}}$ \\
\hline 4 & Initial carapace length (mm) & $66.23 \pm 0.70$ & $65.00 \pm 3.06$ & $64.82 \pm 1.06$ & $66.36 \pm 2.82$ \\
\hline 5 & Final carapace length (mm) & $66.95 \pm 0.35$ & $66.82 \pm 2.12$ & $65.45 \pm 3.36$ & $66.85 \pm 2.12$ \\
\hline 6 & $\begin{array}{l}\text { Carapace length gain } \\
(\% / \text { day })^{*}\end{array}$ & $1.08^{\mathrm{b}}$ & $2.80^{\mathrm{c}}$ & $0.97^{\mathrm{b}}$ & $0.73^{\mathrm{a}}$ \\
\hline 7 & Molted & 16 & 20 & 14 & 12 \\
\hline 8 & FCR & 4.18 & 2.82 & 4.26 & 4.76 \\
\hline 9 & SR $(\%)$ & 90.90 & 100 & 90.90 & 90.90 \\
\hline
\end{tabular}

*Values with the same superscript are not significantly different. 
Among the lobsters injected with thyroxine hormone at a dose of $0.1 \mu \mathrm{g} / \mathrm{g}, 20$ had molted, while only 16 of those injected with thyroxine hormone at a dose of $0 \mu \mathrm{g} / \mathrm{g}$ had molted. The lowest numbers of molted male spiny lobsters were found in those injected with thyroxine at doses of 0.2 and $0.5 \mu \mathrm{g} / \mathrm{g}-14$ and 12 males, respectively (Table 1). The FCR of the male spiny lobsters injected with $0.1 \mu \mathrm{g} / \mathrm{g}$ thyroxine hormone was the lowest (2.82) of the $0,0.2$, and $0.5 \mu \mathrm{g} / \mathrm{g}$ doses, which corresponded to the FCRs of 4.18, 4.26, and 4.76, respectively (Table 1). The highest SR of the male spiny lobsters over the 70-day cultured period was found in those injected with thyroxine hormone at a dose of 0.1 $\mu \mathrm{g} / \mathrm{g}$, of whom $100 \%$ survived, compared to those injected with thyroxine hormone at doses of $0,0.2$, and $0.5 \mu \mathrm{g} / \mathrm{g}$, which had an average SR of $90.9 \%$ (Table 1). The male spiny lobsters injected with thyroxine at a dose of $0.1 \mu \mathrm{g} / \mathrm{g}$ were also bigger than those injected with doses of $0 \mu \mathrm{g} / \mathrm{g}$ (Figure 4).

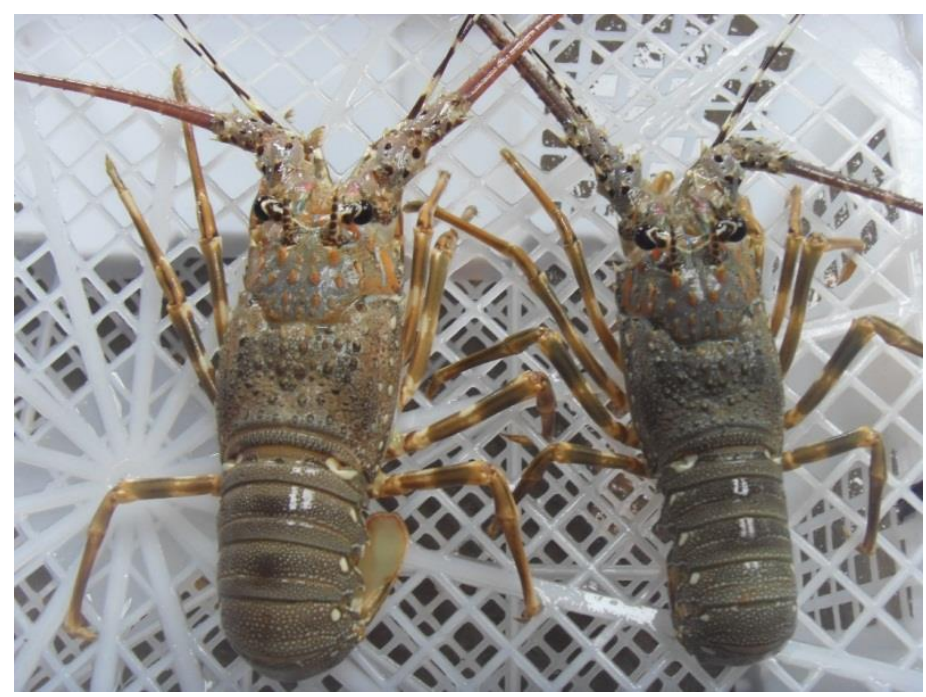

Figure 4. The male spiny lobster (Panulirus homarus) injected with thyroxine hormone at a dose of $0.1 \mu \mathrm{g} / \mathrm{g}$ (left) is bigger than the male spiny lobster injected with thyroxine at a dose of $0 \mu \mathrm{g} / \mathrm{g}$ (right).

\section{DISCUSSIONS}

Gonadal maturation research has recently only focused on female brood stocks because they are related to egg production and larvae production. Male brood stocks, however, also play an important role in reproduction, because female brood stocks need abundant, highquality sperm for fertilization (Minagawa, 1999). The need for high-quality spiny lobster brood stock for hatcheries may be met with culture-based brood stocks (Jones, 2009). Brood-stock rearing is a basic step in hatcheries or closed aquaculture systems, including gonadal maturation and the growth of the brood stock (Hall et al., 2013).
Recent research has found that the limited number of mature male spiny lobsters and stunted brood stocks are due to overfishing for human consumption (Adiputra et al., 2018). Moreover, if male spiny lobsters are easy to provide, it is only in immature conditions, unacceptable sizes, and limited numbers, in contrast to female lobsters (Jong 1993). To obtain gonadal, mature male spiny lobsters, the lobsters need to reach optimum body weight and thus require longer rearing and maintenance.

The thyroxine hormone accelerates this growth, generating an optimum body weight and level of gonadal maturation, which are required to function optimally during spawning. Normally, mature male 
spiny lobsters need longer culture periods; manipulating their growth using thyroxine eliminates this need.

This potential use of thyroxine is amply supported by the dramatic change in the GSI and gonad weight of the male lobsters due to thyroxine injection, which contrasted strongly with the male spiny lobsters that received no thyroxin (Figure 1). The thyroxine likely had such a profound effect on the GSI because it plays a role in mass sperm production or spermatogonia production (Radha \& Subramoniam, 1985), both of which will eventually increase gonad weight. However, Minagawa (1999) found that the GSI of mature male $P$. japonicus did not exhibit any significant changes during the season, even though spermatogenesis was detected in their testes and the sperm were available in their vas deferens.

The anatomies of the vas deferens and testes indeed changed significantly in male spiny lobsters that were injected with thyroxine at a dose of $0.1 \mu \mathrm{g} / \mathrm{g}$, while no change was detected in male spiny lobsters injected with no thyroxine (Figure 2). The changes in gonadal maturity observed in this experiment were similar to the results reported by Nakamura (1990), namely, that the maturity of the male $P$. japonicus gonad could be observed by measuring the changes in the sizes of the vas deferens and testis. Minagawa and Higuchi (1997) stated that male $P$. japonicus weighing more than $120 \mathrm{~g}$ are "functional" males, sperm easily being found in their vas deferens.

Slow growth, on the other hand, has been observed in spiny lobsters that were not economically viable because of longer culture periods. The puerulus in floatingnet cages in Lombok, Nusa Tenggara Barat required two years of culturing to reach 200-300 g of body weight (Jones, 2010). However, the results of Jong (1993) showed that male spiny lobsters grow faster than females reared either separately or in the same tanks, indicating a great opportunity to develop a technique to raise and grow male spiny lobsters with thyroxine to accelerate their growth even more.

A notable observation is that the specific lobster growth rates in this study differed from previous studies. Athithan and Akannan (2015) reared and raised spiny lobsters, finding that their SGR ranged from $0.29-0.34 \%$ per day. Rathinam et al.'s $(2009,2014)$ results also showed the SGR of spiny lobsters to be from 0.15$0.23 \%$ per day and $0.35-0.68 \%$ per day, respectively. The differences in SGR may be caused by feed variation and its varying protein contents. Improving the feeding and rearing management of spiny lobsters is apparently necessary, then, to optimize their daily growth rate.

Also, the numbers of molting spiny lobsters in those injected with four doses of thyroxine were high. The highest molting rate in the male spiny lobsters injected with thyroxine at a dose of $0.1 \mu \mathrm{g} / \mathrm{g}$ indicates their growth acceleration. This result is similar to that found by Pillai et al. (1987), who found that lower doses of thyroxine increased growth resulted in higher molting frequency in the post larvae of black tiger shrimp. In addition to thyroxine hormone injection, Vijayakumaran et al. (2010) stated that the molting and growth of spiny lobsters can be triggered by the physical contact between spiny lobsters cultured in groups in contrast to those cultured individually, which could be the reason for the higher number of molting spiny lobsters raised in tanks in this study.

The lowest FCR was found in male spiny lobsters injected with thyroxine at a dose of $0.1 \mu \mathrm{g} / \mathrm{g}$, indicating that a minimal dosage of thyroxine supports effective metabolism for nutrient absorption, providing energy for growth. Male spiny lobsters without thyroxine injections and those injected with higher doses of thyroxine $(0.2$ and $0.5 \mu \mathrm{g} / \mathrm{g})$ did not as 
effectively metabolize the consumed feed. However, the results of another experiment (Athithan \& Akannan, 2015) showed that the FCR of male spiny lobsters reared in growing tanks ranged from 2.51-2.62 with tight feed control and a strict rearing technique.

No mortality at all was recorded in the male spiny lobsters injected with thyroxine at a dose of $0.1 \mu \mathrm{g} / \mathrm{g}$. However, one male spiny lobster died with each dose of the thyroxin injection of $0,0.2$, and 0.5 $\mu \mathrm{g} / \mathrm{g}$. Interestingly, in male spiny lobsters injected with thyroxine at doses of 0.2 and $0.5 \mu \mathrm{g} / \mathrm{g}$, the dead lobsters exhibited moltdeath syndrome, showing the failure to complete the molting process during life, especially in its early stages. Evans (2003) stated that the causes of molt-death syndrome are varied, but that it is related to the role of metabolism, homeostasis, and the process of molting that was not completed in replacing the old cuticle. Molt-death syndrome is also related to the inability of the lobster to provide energy in long duration during molting prior to death. The major benefit of the tank-based culture was the high lobster SR, in contrast to more common methods, such as floating-net cages. The results of Athithan and Akannan (2015) also showed a high SR of $87-89 \%$ in spiny lobsters with this method, in addition to the protection from cannibalism that it affords.

Injection of thyroxine hormone in male spiny lobsters can support two processes at the same time, that is, gonad maturity and growth. This experiment also confirmed the findings of Lipcius and Herrnkind (1987), who discovered that, in adult $P$. argus, a large size preceded gonadal maturation and spawning, immaturity and a small size preceded molting, and a medium size preceded molting before spawning, with environmental factors, such as photoperiodicity and temperature, influencing the process. The results of this experiment are the preliminary data showing the advantages of applying thyroxine to male spiny lobsters to accelerate their gonad maturation and growth, hopefully to eventually influence spiny lobster hatchery techniques and aquaculture in general. Furthermore, thyroxine not only has the above benefits but is also cheap and reliable.

\section{CONCLUSIONS}

Injection of thyroxine hormone at a dose of $0.1 \mu \mathrm{g} / \mathrm{g}$ affects the gonadosomatic index, the gonad anatomy, the spermatogonia availability, the specific growth rate, the molting, the survival, and the feed conversion ratio of male spiny lobsters.

\section{ACKNOWLEDGMENTS}

The research on male spiny lobsters was funded by the Penelitian Disertasi Doktor Grant from Kemenristekdikti with the contract number No. 062/SP2H/LT/DRPM/2018 granted to first author. We have much appreciation for Balitbangda of Lampung Province, which awarded us the growth study of male spiny lobsters for Anugerah Inovasi Daerah 2017.

\section{REFERENCES}

Adiputra, Y. T., Hudaidah, S., Brite, M., Saputra, A. B., Halim, D.N.A., \& Firmansyah (2018). Spiny lobster fisheries development in Lampung Province. Jurnal Inovasi Pembangunan, 6, 49-59.

Athithan, S. \& Akannan, A. G. (2015). Growth assessment of spiny lobster (Panulirus homarus) under open sea cage culture in Tharuvaikulam of 
Tamil Nadu Coast, South India. The Bioscan, 10, 1655-1658.

Ayson, F. G. \& Lam, T. J. (1993). Thyroxin injection of female rabbit fish (Siganus guttatus) brood stock: changes in thyroid hormone levels in plasma, eggs, and yolk-sac larvae, and its effect on growth and survival. Aquaculture, 109, 83-93.

Bell, T. A. \& Lightner, D. V. (1988). A Handbook of Normal Penaeid Shrimp Histology. Baton Rouge, LA: World Aquaculture Society.

Bhujel, R. C. (2008). Statistics for Aquaculture. Ames, IA: WileyBlackwell.

Ebberson, L. O. E., Björnsoon, B. T., Stefansson, S. O., \& Ekström, P. (2000). Free plasma thyroxine levels in coho salmon, Onchorhynchus kisutch, during parr-smolt transformation: comparison with total thyroxine, total triiodothyroxine, and growth hormone levels. Fish Physiology and Biochemistry, 22, 4550.

Einarsdóttir, I. E., Silva, N., Power, D. M., Björnsson, H., \& Björnsson, B. T. (2006). Thyroid and pituitary gland development from hatching through metamorphosis of teleost flatfish, the Atlantic halibut. Anatomy Embryology, 211, 47-60.

Evans, L. H. (2003). Rock Lobster Autopsy Manual. Bentley, Australia: Muresk Institute, Curtin University of Technology.

Hall, M. R., Kenway, M., Salmon, M., Francis, D., Goulden, \& E.F., Høj, L. (2013). Palinurid lobster larval rearing for closed-cycle hatchery production. In Allan, G. \& Burnell, G. (Eds.), Advances in aquaculture hatchery technology. UK: Woodhead Publishing.

Iromo, H., Zairin Jr., M., Suprayudi, M. A., \& Manalu, W. (2014a). Thyroxine distribution in hemolymph, hepatopancreas, ovary, sponge, and larvae of female mud crabs (Syclla serrata) during ovarian maturation. Journal of Crustacean Biology, 34, 760-763.

Iromo, H., Zairin Jr., M., Suprayudi, M. A., \& Manalu, W. (2014b). Effectivity of thyroxine hormone supplementation in ovarian maturation of female mud crab (Scylla serrata). Pakistan Journal of Biotechnology, 11, 79-86.

Iromo, H., Zairin Jr., M., Agus, M. S., \& Manalu, W. (2015). Supplementation doses of thyroxine hormone of broodstock mud crab (Scylla seratta) during ovarian maturation. Journal Aquaculture Research and Development, 6, 379. 4 pp.

Jones, C. M. (2009). Advances in the culture of lobsters. In Burnell, G. \& Allan, G. (Eds.), New technologies in aquaculture. UK: Woodhead Publishing Limited and CTC Press LLC.

Jones, C. M. (2010). Tropical spiny lobster aquaculture development in Vietnam, Indonesia and Australia. Journal of the Marine Biological Association of India, 52, 304-315.

Jong, K. J. (1993). Growth of the spiny lobster Panulirus homarus (Linnaeus, 1758), depending on sex and influenced by reproduction (Decapoda, Palinuridae). Crustaceana, 64, 18-23.

Kamangar, B. B., Rasae, M. J., Amiri, B. M., Abtahi, B., \& Bahmani, M. (2007). Correlation between circulating insulin-like factor growth 
factor-I and thyroxine and cortisol hormone levels, and some biometrical traits in female brood stocks during the late stages of sex maturation and in juvenile Persian sturgeon (Acipenser persicus). Fish Physiology and Biochemistry, 33, 249-257.

Lipcius, R. N., Herrnkind, W. F. (1987). Control and coordination of reproduction and molting in the spiny lobster Panulirus argus. Marine Biology, 96, 207-214.

Minagawa, M., Higuchi, S. (1997). Analysis of size, gonadal maturation, and functional maturity in the spiny lobster Panulirus japonicus (Decapoda, Palinuridae). Journal of Crustacean Biology, 17, 70-80.

Minagawa, M. (1999). Quantitative analysis of the seasonality of male reproduction in the spiny lobster Panulirus japonicus (Decapoda:Palinuridae). Journal of Crustacean Biology, 19, 276-282.

Nakamura, K. (1990). Maturation of the spiny lobster Panulirus japonicus. Memoirs Faculty of Fisheries Kagoshima University, 39, 129-135.

Nelson, E. R. \& Habibi, H. R. (2009). Thyroid receptor subtypes: structure and function in fish. General and Comparative Endocrinology, 161, 90-96.

Phillips, B. \& Matsuda, H. (2011). A global review of spiny lobster aquaculture. In Fotedar, R. K. \& Phillips, B.F (Eds.), Recent advances and new species in aquaculture. UK: Blackwell Publishing.
Pillai, S. M., Verghese, P. U., Ravichandran, \& Roy, A. K. (1987). Effect of thyroxine on growth and moulting in Penaeus monodon Fabricius. Indian Journal of Animal Science, 57, 241-245.

Priyambodo, B., Jones, C. M., \& Sammut, J. (2017). Improved collector design for the capture of tropical spiny lobsters, Panulirus homarus and $P$. ornatus (Decapoda: Palinuridae), pueruli in Lombok, Indonesia. Aquaculture, 479, 321-332.

Radha, T. \& Subramoniam, T. 1985. Origin and nature of spermatophoric mass of the spiny lobster Panulirus homarus. Marine Biology, 86, 13-19.

Rathinam, A. M. M., Kandasami, D., Kizhakudan, J. K., Leslie, V. A., \& Gandhi, A. D. (2009). Effect of dietary protein on the growth of spiny lobster Panulirus homarus (Linnaeus). Journal of the Marine Biological Association of India, 51, 114-117.

Rathinam, M. M., Kizhakudan, J. K., Vijayagopal, P., Jayasankar, V., Leslie, V. A., \& Sundar, R. (2014). Effect of dietary protein levels in the formulated diets on growth and survival of juvenile spiny lobster Panulirus homarus (Linnaeus). Indian Journal of Fisheries, 61, 6772.

Roustain, P. \& Gaik, L. A. (2006). Effect of thyroxine immersion on larval survival, growth and postlarvae production of freshwater prawn, Macrobrachium rosenbergii (de Man). Aquaculture Research, 37, 1378-1380. 
Shields, J. D. \& Boyd, R. (2014). Atlas of Lobster Anatomy and Histology. Virginia Institute of Marine Science.

Sullivan, C. V., Bernard, M. G., Hara, A., \& Dickhoff, W. W. (1989). Thyroid hormones in trout reproduction: enhancement of gonadotropinrealising hormone analogue and partially purified salmon gonadotropin induced ovarian maturation in vivo and in vitro. The Journal of Experimental Zoology, 250, 188-195.
Vijayakumaran, M., Anabarasu, M., Kumar, T. S. (2010). Moulting and growth in communal and individual rearing of the spiny lobster, Panulirus homarus. Journal of the Marine Biological Association of India, 52, 274-281. 